\title{
Developing a Model for Managing the Quality of Education in the Republic of Dagestan
}

\author{
Tatyana Kamalova ${ }^{1},{ }^{*}$ Madina Shabanova $^{2}$, Yusup Umavov ${ }^{1}$, Gazalieva Napisat ${ }^{1}$ \\ ${ }^{1}$ Dagestan State University, Russia \\ ${ }^{2}$ Dagestan State Technical University, Russia \\ *Email: kamalova05@mail.ru
}

\begin{abstract}
This article assesses the role of education in ensuring sustainable socio-economic development of the country, region and municipalities. The authors considered approaches to the definition of the essence of the concept of "knowledge economy". Also, we have substantiated the understanding of the quality of education as the basis for reforming the education system in Russia and determined the main problematic zones of the education development in Russian Federation and Dagestan Republic.

The authors of the article propose a mechanism for the formation of a unified system of education quality management in a specific region - the Republic of Dagestan, linking the regional and municipal levels of education management and educational organizations. The authors also developed a process model for managing the quality of education in the Republic of Dagestan, which provides practical recommendations for the development of the education sector in the Republic of Dagestan. The proposed model provides the creation of a unified interconnected organic system that connects both regional and municipal levels of government.
\end{abstract}

Keywords: Quality of education, Regional level, Municipal level, Process model, Educational institutions, Process management, Resource management.

\section{INTRODUCTION}

The development of education is one of the most important foundations for ensuring sustainable socioeconomic development of the country. The 70th UN General Assembly adopted the official document "Transforming Our World: The 2030 Agenda for Sustainable Development" The development of education is also noted [1] among the 17 priority areas of sustainable development.

The importance of education for sustainable development of society is also discussed in the "Information Note on the World

Conference on Education for Sustainable Development in 2014" and in the concept of education adopted in Incheon [2].

That is why, in recent years, more and more attention is paid to the development of the knowledge economy.
This term was first introduced by Fritz Machlup. He used it to refer to a small part of the high-tech sectors of the economy [3].

According to Peter Drucker, the concept of "knowledge economy" should be understood as a system in which knowledge is considered as the main productive force of economic development of all branches of social production [4].

There is also a third point of view, which by the term "knowledge economy" means the economy of knowledgeable people, where the leading factor of production is human capital. A similar point of view is expressed in the UN report "Understanding the Knowledge Society", which examines a model that provides the use of knowledge of all members of society in the reproductive process. At the same time, this model stipulates the need to provide people with the opportunity to manifest this knowledge [5]. 
In modern practice, the concept of the knowledge economy forms the basis for the development of public policy. For example, Chinese knowledge economy is a government strategy. They proceed from the position that economic development is directly related to the development of competition. The effective development of competition at the present stage cannot exist without the development of education [6].

The efficiency of the education system reform directly depends on the degree and quality of the inclusion of the potentials of regions, municipalities and all educational institutions in the process of education reform in the Russian Federation. First of all, this will be reflected in changes in the regional education management system. Sustainable development of the entire system and obtaining the planned level of education will become possible with the establishment of mechanisms and models that include the specifics and conditions of activity of a particular region, municipality and school.

The following can be considered as the main problems of the development of education in Russia today:

- the lack of formation of the all-Russian system for assessing the quality of education;

- insufficient level of development of feedback with society, which hinders the development of competition in the educational sphere, increasing the efficiency and availability of educational services;

- the lag of a number of regions in the implementation of modern approaches to teaching and upbringing, which leads to problems in the development of a unified educational space of the Russian Federation;

- the unresolved problem of ensuring the compliance of training areas in the vocational education system with the demands of the labor market in many regions.

We can notice trends similar to the Russian market in the development of the educational services market in the Republic of Dagestan, and they are further aggravated by the fact that the republic is a depressed region and, in terms of economic development, occupies one of the last places among the subjects of the Russian Federation.

The specific problems of the region include:

- an acute shortage of preschool institutions;

- a large number of schools with 2-3 shifts;

- outdated material and technical base of educational organizations;

- low wages of educators and deteriorating working conditions, which leads to a decrease in the prestige of this profession.

All this necessitates the development of an effective program for the modernization of the regional education system and the formation of a unified system for managing the quality of education in the republic.

\section{PROCESS MODEL OF EDUCATION QUALITY MANAGEMENT IN THE REPUBLIC OF DAGESTAN}

The works of many scientists [7-10] are devoted to the issues of education quality management and represent attempts to develop mechanisms for improving the quality of education.

As such mechanisms E. De Corte [8] considers the processes of self-regulation of students, while G. Schrüfer, K. Wrenger, I. Lindemann, and V. Kurennoy $[9,10]$ propose development of systems thinking and assessment competencies.

Education quality management implies systematic, coordinated actions aimed at improving the educational process in educational institutions, as well as the complex of related basic, managerial and supporting processes.

Figure 1 represents our proposed process model for managing the quality of education in the Republic of Dagestan.

When developing this model, the authors were relying on modern methods and technologies of management based on the philosophy of Total Quality Management - TQM). Total Quality Management TQM, in turn, is based on the quality assurance standards contained in the ISO 9000 series of international standards and the modernized EFQM model - the Government Quality Award model.

\subsection{Improving the education quality management system}

The proposed model provides the creation of a unified interconnected organic system that connects both regional and municipal levels of government. A regional center for monitoring the quality of education is being created under the Ministry of Education of the Republic, which coordinates the activities of education departments of municipalities, through the commissioners for the quality of education introduced into this structure. Which, in turn, regulate the activities of education quality managers in educational institutions of this municipality. The whole process of managing the quality of education in the region is coordinated and regulated by these bodies in cooperation.

For example, managers for the quality of education of educational organizations (schools, kindergartens, etc.), authorized for the quality of education in municipalities, collect, analyze, store and submit data to the regional center for monitoring the quality of education, which summarizes and prepares analytical reports based on monitoring results. 


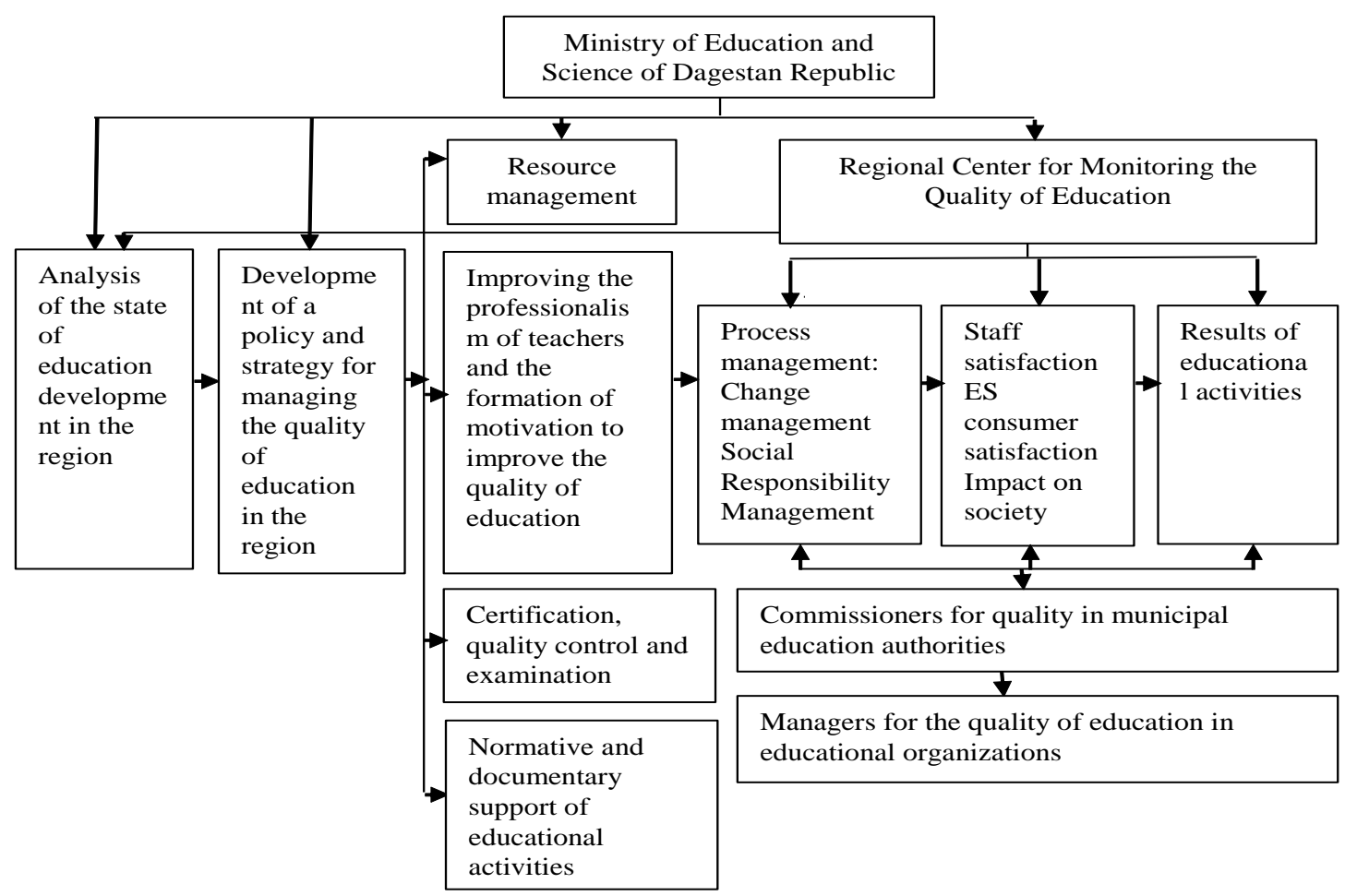

Figure 1 Process model of education quality management in the Republic of Dagestan.

Monitoring requires appropriate training, in this regard, within the framework of the regional center, training officials and teaching staff involved in work in the field of monitoring can be carried out.

In addition, the center is obliged to provide technical support for work in the field of monitoring: create local computer networks and data banks and post analytical reports for review by all subjects involved in the process of education quality management.

\section{PRINCIPLES AND METHODS OF ORGANIZING THE EDUCATION QUALITY MANAGEMENT SYSTEM IN THE REPUBLIC OF DAGESTAN}

The strategy for managing the quality of education in the republic should contain a number of management mechanisms.

First, it is the mechanism for improving the professionalism of teaching staff, which serves as the basis for the formation of motivation to improve the quality of education.

The development and implementation of an effective education quality management system mainly depends on the level of professional qualifications of teachers. The achievement of the result of this task depends on the quality and level of training at the Dagestan State Pedagogical University. In the future, the professional growth of teachers is provided at the expense of two institutions subordinate to the Ministry of Education of the Republic of Dagestan - the Dagestan Institute for the Development of Education and the Dagestan Research Institute of Pedagogy after A.A. Takho-Godi. These institutions, in conjunction with the Regional Center for Monitoring the Quality of Education, are becoming not only a center for professional development of teachers, but also the basis for the development of a quality management system for education in the republic.

In addition, at the level of the Ministry of Education and Science of the Republic of Dagestan, it is possible to use such mechanisms to motivate teachers to improve the quality of education:

- holding a competition in the field of quality for educational institutions and municipalities;

- creation of a republican experimental site on the quality of education on the basis of the Research Institute after Takho-Godi;

- inclusion of quality issues in the program of competitions "school of the year", "teacher of the year", consideration of these issues in the provisions on the certification of educational institutions, teaching staff.

In 2018, the Ministry of Education and Science of the Republic of Dagestan began holding professional competitions for teachers in 12 subjects. The purpose of these competitions is to assess the quality of teaching 
disciplines based on such criteria as the depth of knowledge of the subject, methodological competence and efficiency in the use of modern technological teaching aids.

We must not stay aside from the work on the growth of professional skills of teachers and the education administration of municipalities, which through their authorized representatives must organize seminars and meetings for specialists of educational institutions in the field of quality and provide consulting services for educational institutions. Educational institutions themselves can also actively participate in competitions for the quality of education with their innovative training programs, in carrying out various actions in the field of quality.

The important tasks of the Ministry of Education and Science of the Republic of Dagestan in the field of control and audit of quality management systems in educational institutions are the development of a regional system for assessing the quality of education, organizing, conducting and evaluating the results of the unified state exam, accreditation and licensing of educational institutions and statistical control of the quality of education in the region. As part of the implementation of the last competence, the Ministry of Education and Science of the Republic of Dagestan in 2018 released a statistical collection "Key indicators in the field of education of the Republic of Dagestan for 2017/2018."

Particular attention in the education system of the Republic of Dagestan should be paid to assessing the quality of education by graduates. At the moment, such methods as: ensuring the objectivity of the unified state examination, monitoring the quality of knowledge of graduates and, especially, medalists are used.

The use of such monitoring methods and high-quality analytics make it possible to change the situation with the quality of education in the Republic of Dagestan. This aspect is confirmed by statistical data: the average score of the unified state exam in the Russian language increased by 12 points and by 8.5 points in mathematics. Thus, in 2018, compared to 2015, the number of graduates who did not receive a certificate decreased by 3.7 times.

Education departments of municipalities of the Republic of Dagestan are obliged to take part in the procedures for attestation and accreditation of educational institutions and teaching staff as well as to carry out an examination of the quality of basic educational programs, programs of additional education for children and programs for the development of educational institutions.

During the certification of educational institutions, the assessment criteria must include a block for analysis and assessment of quality management systems of educational institutions.
An important component of our proposed model is process management, which includes development management and social responsibility management. These are the issues that the regional center for monitoring the quality of education should deal directly, along with monitoring. Achievement of the modern quality of education is impossible without constant innovative development, which should include the development of an innovation strategy and a program for the development of the republican educational system. Within the realisation of such a program, we should provide for the holding of conferences, competitions of educational organizations and municipalities for the implementation of innovative activities and the creation of experimental sites. As an example we can use the strategic program for the development of the "AllRussian Engineering Center for Microsatellite Competencies" on the basis of the Dagestan State Technical University, as well as the creation of the "Sirius-Altair" Educational Center for Gifted Children.

Educational institutions are also obliged to be included in innovation activities through the implementation of registers of innovative ideas, developments and creative groups in certain areas of innovation.

Management of the quality of education in the Republic of Dagestan is difficult without a stable relationship between educational organizations and educational management organizations with the population. This is the goal of social responsibility management, which systems are: holding public events of cultural, educational, environmental and patriotic orientation; revelation of materials informing about achievements in quality management of education of the best educational institutions, creation and ensuring the uninterrupted functioning of a specialized website on the Internet to inform the public about the quality of education and measures to improve it, as well as creation and constant interaction with the public council for quality control of education. Today, such a council is organized under the Ministry of Education of the Republic of Dagestan. All these activities should be within the competence of the Regional Center for Monitoring Education Quality.

A good source for assessing the population's satisfaction with the quality of education is a quarterly analysis of publications in the media, letters, complaints, appeals to state and municipal authorities related to the poor quality of educational services.

In addition, it is possible to use episodic sections in educational institutions of secondary, vocational and additional education of schoolchildren and students on the issue of satisfaction with the school, college and the quality of the education they provide. 


\section{CONCLUSIONS}

The implementation of the proposed process model for managing the quality of education in the Republic of Dagestan, in our vision, will allow us to achieve the following results:

- improving the coefficient of accessibility of quality education, which must meet the requirements of the modern needs of the development of society;

- increasing the professional qualities of the teaching staff of educational institutions on the basis of the obligatory participation of the teaching staff in advanced training programs, both at the regional and federal levels;

- achieving results and innovative development of the education system of the republic as a whole, through the introduction of innovative systems and technologies in educational institutions of preschool, general and vocational education;

- improving the quality of vocational training, containing the optimization of the number of professions and specialties, taking into account the needs of the republican economy;

- expanding the relationship between educational institutions and employers in the training and employment of future specialists.

\section{Conclusions}

The results of the analysis of the current situation in the education system of the republic will serve as the basis for work on further development by the Ministry of Education of the Republic of Dagestan state policy in the field of education and the development of a strategy for managing the quality of education in the Republic of Dagestan.

\section{REFERENCES}

[1] Transforming Our World: The 2030 Agenda for Sustainable Development, Sze, S.M., Physics of Semiconductor Devices, (2015). Retrieved from: https://sustainabledevelopment.un.org/post

[2] Briefing note on the 2014 World Conference on Education for Sustainable Development. Sze, S.M., Physics of Semiconductor Devices, (2015). Retrieved from: http://www.geogr.msu.ru/science/projects/our/docs lindex.php

[3] F. Machlup, Knowledge production and dissemination in the United States, M.: Progress, 1966, 35 p.

[4] Drucker Peter F., Post-capitalist society, Harper Business, 1994, 232 p.
[5] Understanding Knowledge Societies: In Twenty Questions and Answers with the Index of Knowledge Societies. Department of Economic and Social Affairs (DESA). United Nations, New York, 2005.

[6] S.Yu. Trapitsyn, The role and place of universities in the knowledge economy Universum: Bulletin of Herzen University 3-4 (2014) 72-79.

[7] The foreign experience of quality management of educational activities Demina S., Master's Degree student, SEI HPE KhMAD - Yugra «Surgut State Pedagogical University» TRANSPORT BUSINESS IN RUSSIA 2 (2015) 99.

[8] Erik De Corte Learning Design: Creating Powerful Learning Environments for Self-Regulation Skills, Educational issues 4 (2019) 30-46. DOI: https://doi.org/10.17323/1814-9545-2019-4-30-46

[9] Gabriele Schrüfer, Katja Wrenger, Imme Lindemann "Reflectories" for the Promotion of Competences in Education, Educational issues 2 (2020) 152-174. DOI: https://doi.org/10.17323/1814-9545-2020-2-152$\underline{174}$

[10] V. Kurennoy, Philosophy of Liberal Education: The Contexts//Educational issues 2 (2020) 8-36. DOI: https://doi.org/10.17323/1814-9545-2020-2-8-36 